\title{
Comparison of Learning Outcomes Between Using PBL And TAI Viewed From Student's Motivation
}

\author{
Dwi Oktaviani Ogara, Suyanto \\ Universitas Negeri Yogyakarta \\ dwi.oktaviani2016@student.uny.ac.id
}

\begin{abstract}
This study aims to find out: (1) the differences of learning outcomes between student's learning by using PBL model and student's who learn to use TAI model, (2) the difference of the learning outcome between the use of PBL model and TAI model at learners who have high learning motivation, (3) the difference of the learning outcome between the use of PBL model and TAI model at learners who have low learning motivation and (4) the interaction effect between of learning models and student's motivation to learning outcomes. This was a quasiexperimental research study employing the factorial $2 \times 2$ design. The research population is the XI grade social class of SMA Negeri 1 Ngaglik, totaling 94 student's. The sample was selected using simple random sampling technique. The data analysis used the variant analysis (Anava) two way with significance level of (a) 0.05 .
\end{abstract}

Keywords: Learning Outcomes, Motivation, PBL, TAI

\section{INTRODUCTION}

The overarching goals of the course, however, are the student learning outcomes (Elhabashy, 2017: 12). Success or failure of learning outcomes if there is a change in behavior due to the learning process. According to Maher (2004: 46) it has been recognized that education is related to bringing about change in individuals, and the use of learning outcomes to describe these changes is certainly not a new practice. Learning outcomes as behavioral changes that occur after following the teaching and learning process in accordance with educational goals (Purwanto, 2016: 54).

Based on observation made on class XI IPS students of SMAN 1 Ngaglik in Academic Year $2017 / 2018$ it is known that student learning outcomes are as follows:

Table 1. Midterm Tests Results XI IPS SMAN 1 Ngaglik

\begin{tabular}{lllll}
\hline No. & Class & $\begin{array}{l}\text { Value } \\
<75\end{array}$ & $\begin{array}{l}\text { Value } \\
\geq 75\end{array}$ & Sum \\
\hline 1. & XI IPS 1 & 19 & 13 & 32 \\
2. & XI IPS 2 & 18 & 13 & 31 \\
3. & XI IPS 3 & 16 & 15 & 31 \\
\hline Sum & Total & 53 & 41 & 94 \\
& Percentage & 56.4 & 43.6 & 100 \\
\hline
\end{tabular}

Based on Table 1, it can be seen that students' economic learning outcomes are still low. It can be seen from 94 students, the number of students who have reached the KKM standard there are 41 students or $43.6 \%$, while students who have not reached the KKM are 53 students or $56.4 \%$. The low value of students showed that the economic learning objectives at SMAN 1 Ngaglik have not been achieved because the learning outcomes have not yet reached the KKM which is applied to economic subjects that is 75 . The criteria student success rates are as follows: special or maximum: if all the learning material can be known by students, it is very good / optimal: if most ( $76 \%$ to $99 \%$ ) the material taught can be known by students, good / minimum: if the subject matter taught is only $(60 \%$ to $75 \%$ ) controlled by students, less: if the teaching material taught is less than $60 \%$ controlled by students (Djamarah \& Zain, 2013: 107).

Factors that cause the failure of learning objectives at SMAN 1 Ngaglik can be seen from several factors, one of which is motivation. Learning motivation is an internal and external encouragement to students who are learning to make behavioral changes (Uno, 2016: 23). Students who are motivated to learn will have a success that those who are not (Hodges, 2004: 1). In reality, motivation 
in learning sometimes rises so rapidly but also drops drastically because it needs an effort to motivate learners (Siregar \& Nara, 2014: 55).

One of the important goals of education is to improve academic achievement and knowledge (Nikou et al., 2014: 936). One effort that can be to apply the PBL learning model and the TAI learning model. According to Armitage et al. (2015: 1) PBL is a pedagogical approach that encourages those who take part in processes and supportive change agents working in collaboration with colleagues, and also as individuals to use their creativity in finding solutions to practical problems. This learning is done through the process of knowing and solving a problem (Azer, 2008: 10). By learning through problems and finding alternatives to their solutions, students can learn directly through experience. The experience will be experiential and learning outcomes and can lead to multiple advantages (Wang, 2016: 354). The teacher in PBL encourages students to use logical thinking to give a problem, there is a developing higher order thinking skills (Abanikannda, 2016: 56).

TAI model is one type of cooperative learning with individual assistance (Suyanto \& Jihad, 2013: 150). TAI model is very interesting because it implements a combination of two things: learning with individual and group abilities. According to Tilaar (2014: 26) TAI is type of learning combines the advantages or learning in group work and individual learning. Peer-assisted learning associated with team-based learning is a valuable enhance learning strategy among students (Kawas \& Hamdy, 2017: 42). According to Rudi (2017: 71). The students can be solved together with the group leader and with guidance from the lecturer.

Research results from Yanti, Dwi \& Martyana (2015) show that the Team Assisted Individualization model with constructivism approach to student learning achievement in the derivative material of class XI functions is effective. Furthermore, the same thing as the results of Ningsih, Mardiyana \& Gatut (2014) said that the TAI model with the snowball drilling method produced better learning achievement in Mathematics than the TAI type and direct learning model, and cooperative learning type models. TAI produces better learning achievements in Mathematics than direct learning models.

Research results from Rahman (2015) have significant differences in the internet-based Problem Based Learning model and lecture learning varies with economic learning achievement, in terms of learning motivation in MA Bany Khozin Jember students. Furthermore, the same webquest problembased learning model of Lestari (2015) proved to be effective to implement in learning activities so as to improve students' economic learning outcomes.

Based on the research results, PBL and TAI models can be applied so students are active in the learning process. However, economic teachers at SMAN 1 Ngaglik did not implement a variety of learning models, especially PBL and TAI models. Therefore, there needs to be an effort to implement PBL and TAI in the process of economic learning in SMAN 1 Ngaglik. In this study researchers wanted to learning outcomes between students who learned using the Problem Based Learning model and students who learned using the Team Assisted Individualization model for students who were high and low motivated.

\section{THEORITICAL SUPPORT}

The learning process occurs because of a goal that must be achieved by students in the form of learning outcomes. Learning outcomes include desirable outcomes that students expect from participating in any particular program of higher education (Nygaard et al., 2009: 18). It can be said that learning outcomes are the basis used to determine the success of students in mastering the subject matter. According to Taurina (2015: 2626) learning outcomes are described as written statements of what a learner is expected to know, understand and can do at the end of a period of learning. Assessment of learning outcomes can provide an overview of information to the teacher about the progress of students in an effort to achieve learning goals through the activity of learning. Learning outcomes describe measurable skills, abilities, knowledge, or values that students should have (Paolini, 2015: 24). In order for the teacher to be able to develop all potential students, the teacher must understand the characteristics of the student. According to Erdogan et al. (2008: 32) for achieving 
targeted success levels depends on understanding the learners. Thus, the success of student learning outcomes can be obtained. In this case the teacher is required to be able to develop all the potential that students have optimally by creating a teaching and learning process that can encourage and motivate students.

One of the most important elements of the learning process that can determine learning outcomes is motivation. There is a tendency for better student motivation, it can be estimated that he will have a good learning achievement (Sulisworo \& Suryani, 2014: 62). Motivation is very closely related to the needs and goals that are in a person. Motivation is the concept that elucidates the direction, persistence and goal directed behavior of a person (Ullah et al., 2013: 91). The purpose of learning motivation for a teacher is to be able to move or spur students so that there can be a desire and willingness to improve student learning outcomes. According to Feng et al. (2013: 56) learning motivation is a result of reinforcement. Enabling students to obtain key to improving students' learning motivation in learning process. Both learning motivations and learning Achievements are influenced by each other. Motivation is needed in order to achieve learning goals in order to obtain the desired results.

One way to motivate students in the learning process is to use PBL and TAI models. According to Flint (2007: 13) PBL is a method of learning in which students first encounter a problem, followed by a student-centered inquiry process. Where it can train and develop sensitivity, foresight and ability to see and solve problems with building a frame of mind. The learning activities started with problems. After they encounter the problem, they have to find their own information, knowledge and sources in order to find the appropriate solution (Sulaiman, 2013: 52). This can cause students to have critical thinking skills. According to Rahman et al. (2016: 251) skills that students learn from PBL approach will finally mold them to be selfindependent and critical thinkers in the future. In the implementation of the Problem Based Learning model the role of the teacher as a facilitator in group discussions. According to Gonzales and Batanero (2016: 16) the problem. The teacher provides the students with appropriate problems to work in learning processes, assists them in identifying material, gives feedback and support during the problem solving process (Apriliadewi, 2017: 12). Therefore, Problem Based Learning is a model used to make students active and responsible for their own learning under the guidance of the teacher as a facilitator.

The TAI model adapts learning to individual differences with regard to student abilities and student achievement (Suyitno, 2004: 67). This method considers the differences in the ability of each student to achieve learning achievement. According to Mosun (2014: 31) so it is not lit. if it is lit. on a variety of strategies, to be able to guide and help each individual. TAI method is the process of learning which students as a center (student center style) that encourages students to be active in teaching learning processes (Sulaiman, 2016: 931). Learning in Team Assisted Individualization starts with the tests given by the teacher. The teacher gave a test as the basis for the formation of study group (Pramestasari \& Qohar, 2016: 74). In this test, students cannot help each other between group members. According to Widodo et al. (2017: 195) the final test is done individually, students are not allowed to help each other and has been noticed by the students. The success of individuals in tests also contributes to supporting group success.

\section{METHOD}

This research is a quasi experiment research or quasi-experimental. This research uses factorial design or $2 \times 2$ factorial design. Factorial design is an action against one or more variables that are manipulated simultaneously in order to study the influence of each variable on the dependent variable or the influence caused by the interaction between several variables (Sukardi, 2011: 187). This factorial design has two values, namely experimental variables (manipulated independent variables) and control variables that have been divided into 2 levels.

This research was carried out at SMAN 1 Ngaglik Yogyakarta. This research was carried out in the even semester of 2017/2018 school year in April to May 2018. The population of the study was 94 students of class XI IPS in SMAN 1 Ngaglik 
Yogyakarta. The sample in this study amounted to 63 students spread into 2 classes, namely class XI IPS 1 as many as 32 students and class XI IPS 3 as many as 31 . The sample in this study was taken using simple random sampling technique. Eriyanto (2007: 73) suggests that this technique is used because the population is not large and has homogeneous characteristics. This is in accordance with the characteristics of the population in this study, namely XI IPS 1, XI IPS 2 and XI IPS 3 which have relatively similar academic abilities because there is no grouping of students based on the superior class, or there is no difference between one class to another.

This type of quantitative research, with primary data obtained from economic learning outcomes tests and learning motivation questionnaires. Learning out comes test instrument and learning motivation questionnaire were first tested for validity by asking expert judgment and then tested in class XI IPS 2 at SMAN 1 Ngaglik. The calculation of the validity of the questionnaire on learning motivation using CFA, while the validity test of learning outcomes using the Iteman program. Test Reliability using Cronbach Alpha is required to be more than 0.6 . The collected data is then tested for prerequisites which include normality test and homogeneity test. The data analysis technique used was two-way variant analysis (ANOVA) with $a=0.05$.

The primary data collected are data on economic learning outcomes with multiple choice tests and learning motivation data with questionnaires. Questions in the test of learning outcomes are related to class XI economic learning material on international economic cooperation. As well as in questionnaire questions related to learning motivation variables.

The instruments in this study are learning outcome tests and learning motivation questionnaires. Learning outcomes test uses a written test in the form of multiple choice test. The total number of questions is 22 items with five alternative answer choices. Score 1 for the correct answer and score 0 for the wrong answer. The questionnaire used in this study is a closed questionnaire with 27 statements. Criteria for arranging questionnaires using a Likert scale consisting of five alternative categories of answers.

Data analysis techniques used in this study are descriptive statistical techniques. Descriptive statistical analysis consists of: maximum, minimum, mean, mode, median values. In this section the data is analyzed one by one based on the respondent's answers compiled from the learning outcomes test and the questionnaire that was filled in by the respondent during the study. This study uses twoway ANOVA for data analysis. Before two-way ANOVA is carried out, an analysis prerequisite test consists of normality test and homogeneity test. If the analysis prerequisite test is fulfilled, the hypothesis test can be carried out.

\section{RESULT AND DISCUSSION}

Data of student learning outcomes in experimental class 1 and experimental class 2 are presented in table 2 .

Table 2. Economic Learning Outcome Data

\begin{tabular}{lllll}
\hline & Exp. 1 & Exp. 1 & Exp. 2 & Exp. 2 \\
\cline { 2 - 5 } Desc. & Pretest & Posttest & Pretest & Posttest \\
\hline Mean & 64.19 & 82.84 & 62.00 & 73.48 \\
Median & 64.00 & 82.00 & 64.00 & 73,00 \\
Mode & 64.00 & 73.00 & 68.00 & 64,00 \\
Min & 50.00 & 55.00 & 50.00 & 64,00 \\
Max & 77.00 & 100.00 & 73.00 & 95,00 \\
\hline
\end{tabular}

Table 2 showed that there are differences in the results of pretest and posttest student learning outcomes, and it can be seen that the initial ability of students in all learning models is the same. Data of student learning motivation in experimental class 1 and experimental class 2 are presented in table 3 below.

Table 3. Student Learning Motivation Data

\begin{tabular}{lllll}
\hline & Exp. 1 & Exp. 1 & Exp. 2 & Exp. 2 \\
\cline { 2 - 5 } Desc. & Pretest & Posttest & Pretest & Posttest \\
\hline Mean & 71.18 & 85.18 & 70.90 & 79.19 \\
Median & 69.50 & 83.50 & 71.00 & 83.00 \\
Mode & 61.00 & 80.00 & 63.00 & 83.00 \\
Min & 58.00 & 75.00 & 58.00 & 69.00 \\
Max & 87.00 & 98.00 & 82.00 & 93.00 \\
\hline
\end{tabular}


Frequency distribution of student learning motivation in experimental class 1 and experimental class 2 is presented in Table 4.

\section{Table 4. Distribution Frequency of Student} Learning Motivation

\begin{tabular}{llll}
\hline \multirow{2}{*}{$\begin{array}{l}\text { Learning } \\
\text { Model }\end{array}$} & \multicolumn{2}{l}{$\begin{array}{l}\text { Economic Learning } \\
\text { Motivation }\end{array}$} & Sum \\
\cline { 2 - 3 } & High & Low & \\
\hline PBL & 20 & 12 & 32 \\
TAl & 12 & 19 & 31 \\
Sum & 32 & 31 & 63 \\
\hline
\end{tabular}

Table 4 showed that in PBL classes there are 20 students who have high learning motivation and 12 students with low motivation to learn motivation. Whereas in the TAI class there are 12 students who have high learning motivation and 19 students with low motivation to learn. Before testing the hypothesis it is necessary to conduct a prerequisite test. The prerequisite test consists of normality test and homogeneity test. The results of normality and homogeneity tests are as follows.

Table 5. The Results of Normality Test

\begin{tabular}{|c|c|c|c|c|}
\hline \multirow[t]{4}{*}{ Variable } & \multirow{2}{*}{\multicolumn{4}{|c|}{$\frac{\text { Kolmogrov-Smirnov Significance }}{\text { Data Group }}$}} \\
\hline & & & & \\
\hline & \multicolumn{2}{|c|}{ Exp. 1} & \multicolumn{2}{|c|}{ Exp. 2} \\
\hline & Pretest & Posttest & Pretest & $\begin{array}{c}\text { Postte } \\
\text { st }\end{array}$ \\
\hline $\begin{array}{l}\text { Learning } \\
\text { Outcome }\end{array}$ & 0,125 & 0,494 & 0,424 & 0,352 \\
\hline $\begin{array}{l}\text { Learning } \\
\text { Motivation }\end{array}$ & 0,274 & 0,706 & 0,267 & 0,088 \\
\hline
\end{tabular}

Table 5 showed that the value of the significance of pretest and posttest motivation and economic learning outcomes have a significance value more than 0.05 . Thus it can be concluded that the data is normally distributed.

Table 6. The Results of Homogeneity Test

\begin{tabular}{lll}
\hline & \multicolumn{2}{l}{ Lavene Statistic Significance } \\
\cline { 2 - 3 } Variable & Pretest & Posttest \\
\hline Learning Outcome & 0.081 & 0.143 \\
Learning Motivation & 0.241 & 0.837 \\
\hline
\end{tabular}

Table 6 showed that the significance value of the results Lavene test has a significance value more than 0.05 . Thus it can be concluded that the variance of both groups is homogeneous.

\section{Hypothesis 1}

Table 7. The Results Two-way ANOVA Test

(Comparison of Learning Outcomes Between Use of PBL Learning Models with TAI Learning Model)

\begin{tabular}{llll}
\hline Learning Models & Average & $\mathrm{F}$ & sig. \\
\hline PBL & 18.81 & & \\
TAl & 11.70 & 6.455 & 0.014 \\
\hline
\end{tabular}

Table 7 showed that from the results of the two-way ANOVA test the average value of the final learning outcomes of PBL was 18.81 and the average final learning outcome was 11.70 with a $F$ count of 6.455 and a significance value of 0.014 . Because $\mathrm{p}=0.014<0.05$, that $\mathrm{H}_{\mathrm{o}}$ is rejected and $\mathrm{H}_{\mathrm{a}}$ is accepted. Thus, it can be concluded that there are differences in learning outcomes between students who learn to use PBL learning models with students who learn to use the TAI learning model.

According to Hajric, et al. (2015: 19) problem solving promotes learners' higher-level thinking skills, and consequently, results in understanding and better application of knowledge. Based on the average value of students' economic learning outcomes the Problem Based Learning model proved to be more effective in improving the learning outcomes of students of class XI IPS at SMAN 1 Ngaglik.

\section{Hypothesis 2}

Table 8. The Results Two-way ANOVA Test (Average Economic Learning Outcomes for Students with High Learning Motivation)

\begin{tabular}{llll}
\hline Learning Models & Average & $\mathrm{F}$ & sig. \\
\hline $\mathrm{PBL}$ & 23.00 & & \\
$\mathrm{TAl}$ & 11.75 & 8.660 & 0.006 \\
\hline
\end{tabular}

Table 8 showed that the results of the twoway ANOVA test obtained the average value of the final learning outcomes of students who use PBL learning models for students who have high learning motivation is 23 and the average final learning outcomes of students who use the TAI learning model for students who have high learning motivation is 11.75 with 8.660 and a significance 
value of 0.006 . Therefore $p=0.006<0.05$, so that $\mathrm{H}_{0}$ is rejected and $\mathrm{H}_{\mathrm{a}}$ is accepted. Thus, it can be concluded that there are differences in learning outcomes between the use of PBL learning models and TAI learning models in students who have high learning motivation.

According to Sulisworo and Suryani (2014: 62) there is a tendency for better student motivation, it can be estimated that he or she will have a good learning achievement. Students are motivated to learn something that will use higher cognitive processes in learning material, so that students will absorb the material better (Riswanto \& Aryani, 2017: 43). Economic learning with the Problem Based Learning model has a significant influence on student learning outcomes with high learning motivation. Thus, this learning model is more effective for students who have high learning motivation because of the great curiosity and diligence and high enthusiasm in learning.

\section{Hypothesis 3}

Table 9. The Results Two-way ANOVA Test (Average Economic Learning Outcomes for Students with Low Learning Motivation)

\begin{tabular}{llll}
\hline Learning Models & Average & $\mathrm{F}$ & sig. \\
\hline $\mathrm{PBL}$ & 6.83 & & \\
$\mathrm{TAl}$ & 12.42 & 4.542 & 0.042 \\
\hline
\end{tabular}

Table 9 showed that the results of the twoway ANOVA test obtained the average value of student learning outcomes using PBL learning model for students who have low learning motivation is 6.83 and the average learning outcomes of students who use the TAI learning model for students who have low learning motivation is 12.42 with a $F$ of 4.542 and a significance value of 0.042 . Because $p=0.042$ $<0.05$, that $\mathrm{H}_{0}$ is rejected and $\mathrm{H}_{\mathrm{a}}$ is accepted. Thus, it can be concluded that there are differences in learning outcomes between the use of PBL learning models and TAI learning models for students who have low learning motivation.

TAI model can help students who have abilities below average so that together they achieve successful learning. According to Slavin (2016: 195 ) by making students work in groups and in equal status, this model will build conditions for the formation of positive attitudes toward students who are less academically and among students from different backgrounds.

\section{Hypothesis 4}

Table 10. The Results Two-way ANOVA Test (Interaction of the Use of Learning Models and Students Motivation to Learning Outcomes)

\begin{tabular}{lllll}
\hline $\begin{array}{llll}\text { Learnin } \\
\text { g Model }\end{array}$ & Learning & Averag & $\mathrm{F}$ & sig. \\
\hline PBL & Hotivation & $\mathrm{e}$ & & \\
& Motivation & & & \\
\cline { 2 - 3 } & Low Learning & 6,83 & & \\
& Motivation & & & \\
\hline TAI & High Learning & 11,75 & & \\
& Motivation & & & \\
\cline { 2 - 3 } & Low Learning & 12,42 & & \\
& Motivation & & & \\
\hline
\end{tabular}

Table 10 showed that the results of the twoway ANOVA test obtained the value of $\mathrm{F} 4.108$ and a significance value of 0.047 . Because $p=0.047$ $<0.05, \mathrm{H}_{0}$ is rejected and $\mathrm{H}_{\mathrm{a}}$ is accepted. Thus, it can be concluded that there is an interaction effect between the use of learning models and learning motivation on economic learning outcomes.

Based on the discussion above, it can be concluded that the Problem Based Learning model is more effective for economic learning in students who have high learning motivation. In addition, the Team Assisted Individualization model is more effective for economic learning in students who have low learning motivation. Thus, the variety of learning motivation possessed by students hence the use of learning models should be adjusted to students' learning motivation and also need to be adjusted to the learning objectives.

Graph of interaction between learning models and learning motivation on student learning outcomes in economic subjects can be seen in the picture below: 


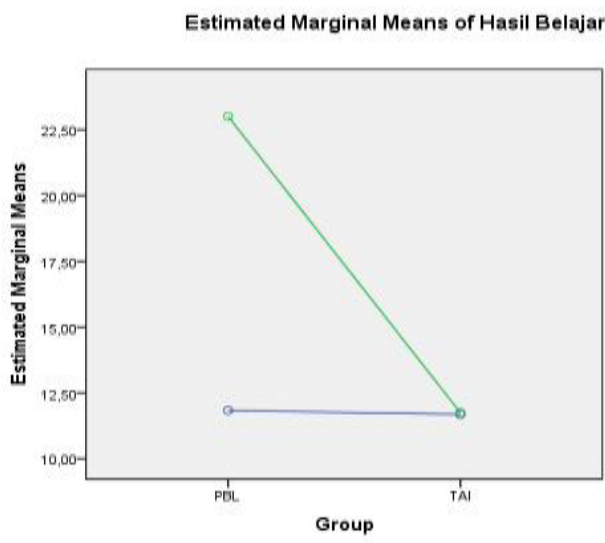

Motivasi Motivasi
- Rendah
Tinggi

Figure 1. Graph of Interaction of Learning Models, Students Motivation and Learning Outcomes

\section{CONCLUSION AND SUGGESTION}

\section{Conclusion}

From the discussion can be concluded as follows. First, there are significant differences in learning outcomes between students who learn using PBL learning models and TAI learning models. Economic learning outcomes of students who learn using PBL learning models are higher than the economic learning outcomes of students who learn to use the TAI learning model. Second, there are significant differences in learning outcomes between the use of PBL learning models and TAI learning models in students who have high learning motivation. The use of PBL learning models is more suitable for economic learning for students who have high learning motivation. Third, there are significant differences in learning outcomes between the use of PBL learning models and TAI learning models for students who have low learning motivation. The use of the TAI learning model is more appropriate for the economic learning of students who have low learning motivation. Fourth, there are significant interaction between the influence of the use of learning models and students' learning motivation on learning outcomes.

\section{Suggestion}

From the discussion, there are several suggestions that can be submitted. First, the teacher needs to pay attention to the motivation of the students before choosing the learning model that will be used in the learning process, so that the chosen learning model matches the characteristics of students. Second, PBL learning model can be used as an alternative learning model, because it has been proven to improve student learning outcomes. Third, the learning process of PBL and TAI learning models takes quite a long time, so the teacher must make thorough preparation and good time management so that the implementation can run optimally. Fourth, to get more optimal results, it is suggested to the next researcher to be able to continue this research on different subject matter or conduct research with a wider scope and scale.

\section{REFERENCES}

Abanikannda. (2016). Influence of Problem Based Learning in Chemistry on Academic Achievement of High School Students in Osun State, Nigeria. International Journal of Education, Learning and Development, 4(3): 5563.

Apriliadewi. (2017). An Analysis of The Implementation of Problem Based Learning in Learning English at The XI Grade Science Class of SMA Negeri 1 Singaraja in The Academic Year 2015/2016. International Journal of Language And Literature, 1(1): 11-19.

Armitage, Andrew, Ole Pihl, \& Thomas Ryberg. (2015). PBL and Creative Processes. Journal of Problem Based Learning in Higher Education, 3(1): 1-4.

Azer, Samy. (2008). Navigating Problem Based Learning. Australia: Elsevier Australia.

Djamarah, Syaiful Bahri \& Aswan Zain. (2013). Strategi Belajar Mengajar. Jakarta: Rineka Cipta.

Elhabashy, Sameh. (2017). Formulate Consequential Student Learning Outcomes. USA: Johns Hopkins University Press.

Erdogan, Yavuz, Servet Bayram \& Levent Deniz. (2008). Factors That Influence Academic Achievemnt and Attitudes in Web Based Education. International Journal of Instruction, 1(1): 31-47.

Eriyanto. (2007). Teknik Sampling: Analisis Opini Publik. Yogyakarta: LKiS.

Feng, Hsiang-Yung, Jin Jun Fan \& Hui-Zhen Yang. (2013). The Relationship of Learning Motivation and Achievement in EFL: Gender as an Intermediated Variable. Educational Research International, 2(2): 50-58. 
Flint, Wendy J. (2007). Problem-Based Learning: Welcome to The "Real World" A Teaching Model For Adult Learners. New York: Word Unlimited.

Gonzalez, Rodriguez \& Fernandez Batanero. (2016). A review of Problem Based Learning Applied to Engineering. International Journal on Advances in Education Research, 3(1): 1431 .

Hajric, Zejnilagic, Sabeta \& Nuic. (2015). The Effects of Problem Based Learning on Students Achievements in Primary School Chemistry. Bulletin of the Chemists and Technologists of Bosnia and Herzegovina, 44: 17-22.

Hodges, Charles B. (2004). Designing to Motivate: Motivational Technique to Incorporate in ELearning Experiences. The Journal of Interactive Online Learning, 2(3): 1-7.

Kawas, S. Al \& Hossam Hamdy. (2017). Peerassisted Learning Associated with Team-based Learning in Dental Education. Health Professions Education, 3:38-43.

Lestari, Ambar Widya. (2015). Pengembangan Model Pembelajaran Problem Based Learning Berbantuan Webquest Dalam Upaya Meningkatkan Hasil Belajar Ekonomi Keals XI IPS SMAN 6 Surakarta. Program Pascasarjana Kependidikan. Universitas Sebelas Maret.

Maher, Angela. (2004). Learning Outcomes in Higher Education: Implications for Curriculum Design and Student Learning. Journal of Hospitality, Leisure, Sport and Tourism Education, 3(2): 46-54.

Mosun, M. 2014. Using Team Assisted Individualization (TAI) in the Music Classroom. Canadian Music Educator. 55(4): 29-31.

Nikou, Farahnaz Rimani, Alireza Bonyadi, \&Khatereh Ebrahimi. (2014). The Effect of Student Team Achievement Division (STAD) on Language Achievement of Iranian EFL Students Across Gender. Journal of Natural and Social Sciences, 3(4): 936-949.

Ningsih, Eka Fitria, Mardiyana \& Gatut Iswayudi. (2014). Eksperimentasi Model Pembelajaran Kooperatif Tipe Team Assisted Individualization dengan Metode Snowball Drilling Terhadap Prestasi Belajar Matematika Ditinjau dari Kemandirian Belajar. Jurnal
Elektronik Pembelajaran Matematika, 2(7): 758-770.

Nygaard, Claus, et al. (2009). Improving Students' Learning Outcomes. Denmark: Copenhagen Business School Press.

Paolini, Allison. (2015). Enhancing Teaching Effectiveness and Student Learning Outcomes. The Journal of Effective Teaching an Online Journal Devoted to Teaching Excellence, 15(1): 20-33.

Pramestasari, Eka Anggraini \& Abd. Qohar. (2016). Aplication of Guided Journal in Cooperative Learning Team Assisted Individualization Type to Support Mathematical Communication Capability of Class VIII A Students at SMPN 2 Malang. IOSR Journal of Research \& Method IN Education, 6(5): 71-76.

Purwanto. (2016). Evaluasi Hasil Belajar. Yogyakarta: Pustaka Pelajar.

Rahman, Mairas Abd, Mohd Nazri Latiff Azmi, Zanirah, Ahmad Taufik Hidayah \& Nor Jijidiana. (2016). The Impact of Problem Based Learning Approach in Enhancing Critical Thinking Skills to Teaching Literature. International Journal of Applied Linguistics and English Literature, 5(6): 249-258.

Rahman, Tri Malikul. (2015). Eksperimentasi Model Pembelajaran Berbasis Masalah (Problem Based Learning)Berbantuan Internet Terhadap Prestasi Belajar Ekonomi Ditinjau Dari Motivasi Belajar Siswa Kelas X Ma Bany Khozin Jember Tahun Ajaran 2013-2014. Program Pascasarjana Kependidikan. Universitas Sebelas Maret.

Riswanto, Ari \& Sri Aryani. (2017). Learning Motivation and Student Achievement: Description Analysis and Relationships Both. The International Journal of Counseling and Education, 2(1): 42-47.

Rudi, La. (2017). Application of Teaching Model of Team Assisted Individualization in Basic Chemistry Courses in Students of Forestry and Science of Environmental Universitas Halu Oleo. International Journal of Education and Research, 5(11): 69-76.

Siregar, Eveline \& Hartini Nara. (2014). Teori Belajar dan Pembelajaran. Bogor: Ghalia Indonesia. 
Slavin, Robert E. (2016). Cooperative Learning: Teori, Riset, dan Praktik. London: Allymand Bacon.

Sukardi. (2011). Metodologi Penelitian Pendidikan Kompetensi dan Praktiknya. Jakarta: Bumi Aksara.

Sulaiman. (2016). The Effectiveness of Team Assisted Individualization in Teaching Vocabulary Viewed from StudentsMotivation. Proceeding of International Conference on Teacher Training and Education UNS, 1(1): 926-932.

Sulaiman, Fauziah. (2013). Physics Students Acceptance of PBL Online in Terms of Learning Outcomes. International Journal of Humanities and Social Sains Invention, 2(3): 50-55.

Sulisworo, Dwi \& Fadiyah Suryani. (2014). The Effect of Cooperative Learning, Motivation and Information Technology Literacy to Achievement. International Journal of Learning and Development, 4(2): 58-64.

Suyanto \& Asep Jihad. (2013). Menjadi Guru Profesional: Strategi Meningkatkan Kualifikasi dan Kualitas Guru di Era Global. Jakarta: Esensi (Erlangga Group).

Suyitno, Amin. (2004). Dasar-Dasar dan Proses Pembelajaran Matematika I. Semarang: UNNES

Taurina, Zane. (2015). Students Motivation and Learning Outcomes: Significant Factors in Internal Study Quality Assurance System. International Journal for Cross-Disciplinary Subjects in Education, 5(4): 2625-2630.

Tilaar, Anetha L.F. (2014). Effect of Cooperative Learning Model Type of Team Assisted Individualization and The Performance Assesment of Learning Achievement to Linier Program Course. International Journal of Science and Engineering Investigation, 3: 25-29.

Ullah, Muhammad Imdad, Aamir Sagheer, Tehmina Sattar \& Shahbaz Khan. (2013). Factors Influencing Students Motivation to Learn in Bahauddin Zakariya University, Multan (Pakistan). International Journal of Human Resource Studies. 3(2): 90:108.

Uno, Hamzah B. (2016). Teori Motivasi \& Pengukurannya: Analisis di Bidang Pendidikan. Jakarta: Bumi Aksara.
Wang, Victor C. X. (2016). Hanbook of Research on Learning Outcomes and Opportunities in the Digital Age. USA: Information Science Reference.

Widodo, Sri Adi, Agustina Sri Purnami \& Rully Charitas Indra Prahmana. (2017). Team Accelerated Instruction, Initials, and Problem-Solves Ability in Junior High School. International Journal on Emerging Mathematics Education, 1(2): 193204.

Yanti, Tri Emma, Dwi Sulistyaningsih \& Martyana Prihaswati. (2015). Keefektifan Model Pembelajaran Kooperative Tipe Team Assisted Individualization dengan Pendekatan Kontruktivisme Terhadap Prestasi Belajar. Jurnal Kajian Pendidikan Matematika, 2(1): 814. 